\begin{tabular}{cc|c}
\hline Tar. Bil. Der. & Tarım Bilimleri Dergisi & Journal of Agricultural Sciences \\
& $\begin{array}{c}\text { Dergi web sayfası: } \\
\text { www.agri.ankara.edu.tr/dergi }\end{array}$ & Journal homepage: \\
& www.agri.ankara.edu.tr/journal
\end{tabular}

\title{
Gamma Rays and EMS Induced Flower Color Mutation in Grasspea (Lathyrus sativus Linn.)
}

\author{
Pegah RAMEZANI ${ }^{a}$, Morteza SIAVOSHI $^{\mathrm{b}}$, Anıl D. MORE ${ }^{\mathrm{c}}$, Mahmoubeh EBRAHIMI $^{\mathrm{b}}$, Salman DASTAN $^{\mathrm{d}}$ \\ 'Islamic Azad University, Ahvaz Branch, Young Researchers and Elite Club, Ahvaz, IRAN \\ ${ }^{b}$ Payame Noor University, Department of Agricultural Science, IRAN \\ ${ }^{c}$ Pune University, Post Graduate Research Station, Department of Botany, Fergusson College, Savitribai Phule, INDIA \\ ${ }^{d}$ Postdoctoral Researcher, Agricultural Biotechnology Research Institute of Iran (ABRII)
}

\section{ARTICLE INFO}

Research Article DOI: 10.15832/ankutbd.385866

Corresponding Author: Pegah RAMEZANI, E-mail: Pegahramezany @ yahoo.com, Tel: +98 (935) 7511402

Received: 12 January 2016, Received in Revised Form: 12 April 2016, Accepted: 12 April 2016

\begin{abstract}
To induce flower color mutants in grasspea (Lathyrus sativus Linn.) variety of Pusa-24, the fresh seeds were exposed to 4 different doses of gamma radiation as physical mutagens (100, 200, 300 and $400 \mathrm{~Gy})$ and treated with 4 different concentration of EMS (ethyl methanesulphonate) as chemical mutagen $(5,10,15$ and $20 \mathrm{mM}$ ) and also combination of both mutagens. Due to mutagenesis broad range of flower color mutants in $M_{2}, M_{3}$ and $M_{4}$ were obtained. Various unique and different flower color mutations like pink, purple, white and yellow detected against blue which is natural color in control progenies. Maximum flower color frequency was recorded in EMS treated seeds $(20 \mathrm{mM})$ in $4^{\text {th }}$ generation and lowest mutation frequency in $2^{\text {nd }}$ generation was obtained in gamma rays $(100 \mathrm{~Gy})$ treated seeds. The results showed that more flower color mutations happened in more dose/concentration of mutagens in every generation.
\end{abstract}

Keywords: Flower color; Mutation; Grasspea; Gamma radiation; EMS

\section{Mürdümük (Lathyrus sativus Linn.)'de Gama Işınımı ve EMS Kökenli Çiçek Rengi Mutasyonu}

\section{ESER BİLGİSI}

Araştırma Makalesi

Sorumlu Yazar: Pegah RAMEZANI, E-posta: Pegahramezany@yahoo.com, Tel: +98 (935) 7511402

Geliş Tarihi: 12 Ocak 2016, Düzeltmelerin Gelişi: 12 Nisan 2016, Kabul: 12 Nisan 2016

\section{ÖZET}

Pusa-24 mürdümük (Lathyrus sativus Linn.) çeşidinde çiçek rengi mutantı oluşturmak için taze tohumlar fiziksel mutajen olarak 4 farklı dozda $(100,200,300$ ve 400 Gy) gama radyasyonu ve kimyasal mutajen olarak da 4 farklı dozda (5, 10, 15 ve $20 \mathrm{mM}$ ) EMS (etil metan sülfonat) ve bunların kombinasyonuna maruz bırakılmıştır. Mutagenesis nedeniyle $M_{2}$, $\mathrm{M}_{3}$ and $\mathrm{M}_{4}$ generasyonlarında geniş boyutta farklı çiçek rengi mutantları elde edilmiştir. Kontrol progenlerinde doğal 
olarak mavi olan çiçek rengine karşın değişik aynı ve farklı olan pembe, mor, beyaz ve sarı çiçek rankleri elde edilmiştir. En fazla çiçek rengi sıklığı 20 mM EMS uygulanmış tohumların 4'üncü generasyonlarında elde edilirken en düşük mutasyon sıklığ1 100 Gy gama 1şını uygulanmış tohumların 2'nci generasyonlarından elde edilmiştir. Bu araştırma sonuçları; her generasyonda yüksek çiçek rengi mutasyonunun yüksek doz/konsantrasyonlarda gerçekleştiğini göstermiştir.

Anahtar Kelimeler: Çiçek rengi; Mutasyon; Mürdümük; Gama radyasyonu; EMS

(C) Ankara Üniversitesi Ziraat Fakültesi

\section{Introduction}

The grasspea (Lathyrus sativus Linn.) $(2 \mathrm{n}=14)$ belongs to the Fabaceae family. It is also known as Indian pea, chickling vetch and khesari commonly use this name in Bangladesh and India. It is an important crop which is appropriate source of proteins. That is generally grown in tropical and subtropical country like Indian subcontinent. Grasspea is a self-pollinated crop. Grasspea can be cultivated in drought ecological condition; it will not affect in any type of heavy rainfall and flood (Kaul et al 1986; Rathod 1989; Campbell et al 1994). Lathyrus sativus Linn. pulses crop having very good strength and ability to develop very strong tap root system, it will help to grow in different types of soil. Lathyrus sativus crops are very strong and resistant to any types of pests (Palmer et al 1989). Lathyrus sativus Linn. is annual herbs, branched or climbing type and dense. The type of inflorescence is recemose and the flowers are axillary, solitary and flower color is blue. Fruits are in the form of pods, which are flat, slightly curved, oblong and bulging over the seeds. Generally, the fruits produced about 4 to 6 seeds in each pod (Campbell \& Clayton 1997). It has proper source of Polyphenols and antioxidant which is beneficial for disease treatment like high fever, jaundice, to control of diabetic cases and cardiac problems.

The initiative target of breeding practices is to increase genetic variability for the better agricultural practices. Success of mutation breeding would appear to be greatest when he is looking for specific mutant not already available and has screening procedures to identify the mutant plant if the mutation is obtained. The mutagen dose administrated should be sufficient to kill about 50 percent of the seed to obtain the maximum number of mutation. Mutation is sudden heritable change in organism, generally the structural change in gene. Mutation may be genic, involving deletion or molecular changes within the physical limits of genes or chromosomal, involving the rearrangement, loss, or duplication of chromosomal segments. Mutation induction in seed offers the possibility of increasing mutation ratio so as several desirable mutations might occur in same seed. Induced mutations are highly effective in enhancing natural genetic resources and have been used improving plants. Gamma radiation and ethyl methanesulfonate (EMS) have been the principal agents employed to increase mutation frequency in plants.

\section{Material and Methods}

The experimental seed material of grasspea (Lathyrus sativus Linn.) variety PUSA-24 collected from Pulses and Oil seed Research Station, Vasantrao Naik Marathwada Agricultural University, Parbhani, Dist-Parbhani, Maharashtra, India. The seeds released by H. K. Jain, Division of Genetics, Indian Agricultural Research Institute, New Delhi, India. The dry seeds of grasspea (Lathyrus sativus Linn.) were treated with gamma rays EMS and, their combination in the present investigation. 300 well filled healthy seeds packed in moist germination paper were selected for each treatment in the gamma chamber at 100, 200, 300 and $400 \mathrm{~Gy}$ doses of gamma rays in ${ }^{60} \mathrm{Co}$ gamma source (irradiation source capacity to release 3000 Ci delivery $7200 \mathrm{r} \mathrm{min}^{-1}$ ). The gamma irradiation installed at Government Institute of Science, Aurangabad (M.S.). EMS treatment was carried out at Department of Botany, Fergusson College, 
Pune, India. Similarly, in case of EMS treatment individually and in combination (EMS+Gamma rays) had done. 300 healthy seeds of each treatment were presoaked in distilled water for 6 hours at room temperature. For EMS treatment, the presoaked seeds were treated with 5, 10, 15 and 20 $\mathrm{mM}$ freshly prepared solution of EMS for 3 hours. For combination treatments 300 seeds each were first irradiated with gamma rays at 100, 200, 300 and 400 Gy doses and then followed by EMS, only one concentration of EMS $(10 \mathrm{mM})$ was used in combination with 100, 200, 300 and 400 Gy treated seeds. Trials and errors have done for selection of appropriate dosage and concentration of mutagens during the project. After different set of trial and error test; have been decided to select such concentration of ethyl methane sulphonate and gamma rays. After the EMS treatment, the treated seeds were washed thoroughly for $1 \mathrm{~h}$ in running tap water to terminate the residual effect of the mutagenic chemicals. After the completion of the treatment the treated seeds were sown immediately in the field along with their respective controls to rise the $\mathrm{M}_{1}$ generation in a completely randomized block design with three replications. All the treatments including the controls were raised adopting a spacing of $30 \mathrm{~cm}$ in between rows and $15 \mathrm{~cm}$ in between plants. All the recommended cultural measures namely, irrigation, weeding and plant production methods were carried out during the growth period of the crop. Developed seeds and seedling percentage has been counts on the basis of number of seeds which stepped seedling stage. All the surviving $M_{1}$ mutant plants were harvested separately at the maturity. The harvested seeds were sown in the next season to raise $M_{2}$ generation. After harvesting of $\mathrm{M}_{2}$ generation seeds, again seeds were sown in the next season to raise $M_{3}$ and same process to raise and harvest $\mathrm{M}_{4}$ generation. The respective control and treatment progenies were observed several times for flower color mutations throughout the crop duration. Observation from budding to flower stages showed different flower color which is mutant effects on plants from $\mathrm{M}_{2}$ till $\mathrm{M}_{4}$ generations. All data statistically analyzed by SPSS software.

\section{Results and Discussion}

The different flower color mutants like white, purple, pink and yellow as against blue in control were observed. Figure 1 show different flower color obtained from application of different concentration and dosage of mutagens.

In present investigation, the mutagenic treatments of EMS, gamma rays and combination of both mutagens were successful in inducing a broad range of flower color mutants in $\mathrm{M}_{2}$ and $\mathrm{M}_{3}$ and $\mathrm{M}_{4}$ generation of grasspea (Figure 2-4).

The highest frequency 2.77 induced by $20 \mathrm{mM}$ of EMS treatment in $\mathrm{M}_{4}$ generation and least frequency 0.068 induced by 100 Gy in $\mathrm{M}_{2}$ generation. The spectrum of flower color mutants like white and purple was found to be wider than that of other mutant types. Majority of mutants were recorded in gamma rays treated seeds by 400 gamma rays, in combination treatment $300 \mathrm{~Gy}+10 \mathrm{mM}$ EMS.

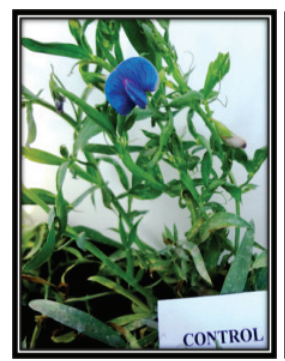

1. Control

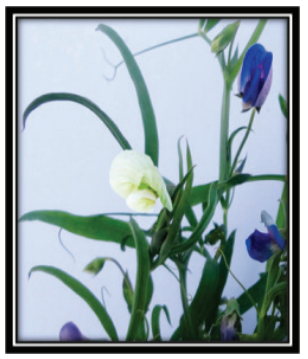

2. White color

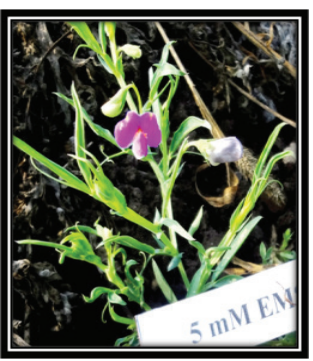

3. Purple color

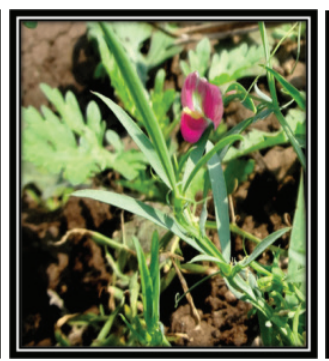

4. Pink color

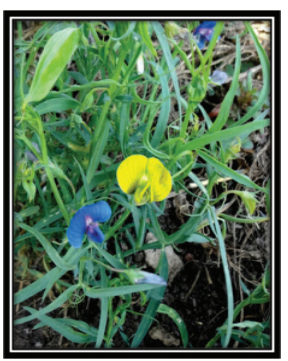

5. Yellow color

Figure 1- Flower color mutants in grasspea 


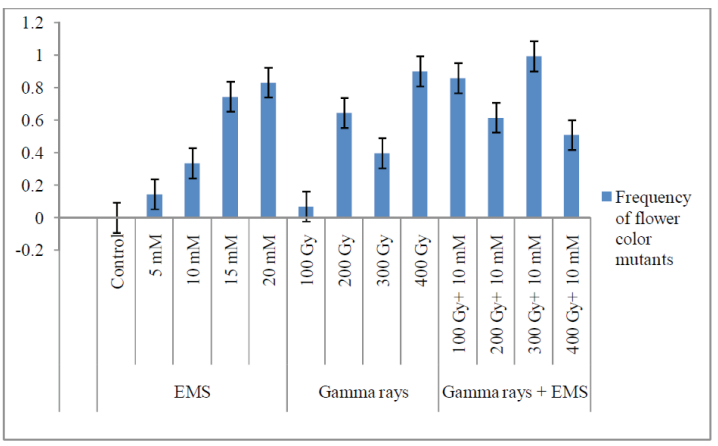

Figure 2- Frequency of flower color in $\mathrm{M}_{2}$ generation of Lathyrus sativus Linn

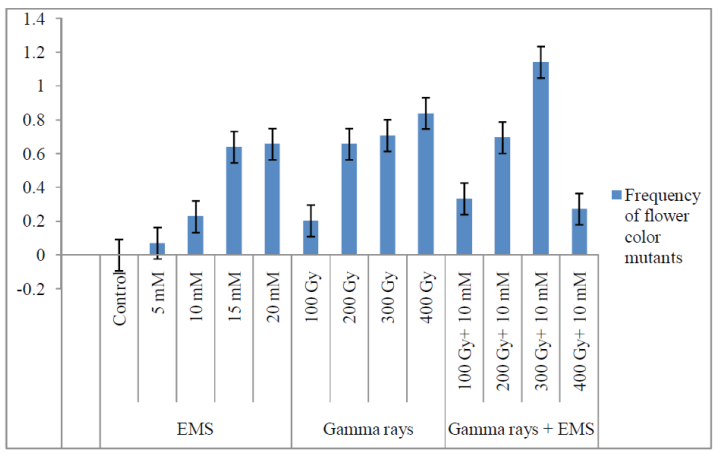

Figure 3- Frequency of flower color in $\mathrm{M}_{3}$ generation of Lathyrus sativus Linn

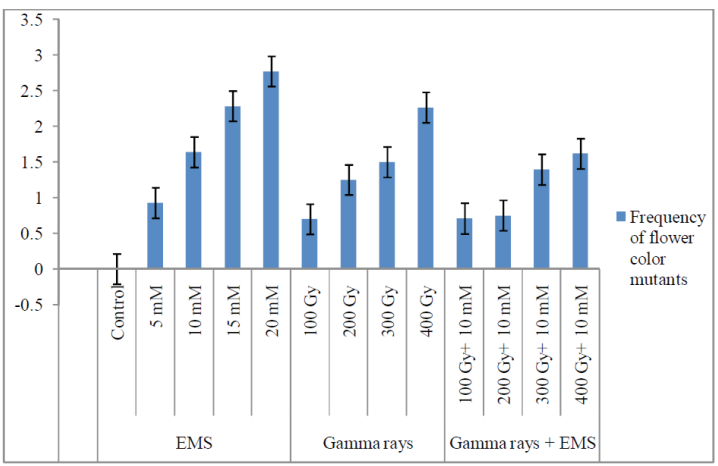

Figure 4- Frequency of flower color in $\mathrm{M}_{4}$ generation of Lathyrus sativus Linn

In the $\mathrm{M}_{3}$ generation of grasspea an increase in the frequency of flower color mutants was noted at majority of the mutagenic treatments followed by $\mathrm{M}_{4}$ generation.

Induced flower color mutation has been recorded in grasspea by Tripathy et al (2011) and in other plants reported like French bean by Borkar \& More (2010) and Mahamune \& Kothekar (2011), in cowpea by Oluwatosin (2001) and Girija et al (2013) and in shoot length of Cicer seeds by Toker et al (2005).

As seen from the figures, in $\mathrm{M}_{4}$ generation values of frequency is more and highest frequency was recorded in $20 \mathrm{mM}$ EMS concentration and lowest frequency take placed in 100 Gy of gamma radiation in $\mathrm{M}_{2}$ generation. The majority of increase has shown from $M_{3}$ to $M_{4}$ frequency.

\section{Conclusions}

In present investigation, the mutants with white flower color strongly were dominant color amongst all flower color which obtained through investigation. The Pusa-24 variety of grasspea showed quite number of viable mutants in $20 \mathrm{mM}$ EMS as compared to all mutagenic treatment in all 4 generations. The maximum frequency was obtained in $20 \mathrm{mM}$ of EMS treated seeds in $4^{\text {th }}$ generation and lowest frequency was recorded in $100 \mathrm{~Gy}$ of gamma rays in $2^{\text {nd }}$ generation. The dose/concentration dependent increase happened in frequency of flower color in every individual and combination treatments. Higher doses and concentration of mutagens showed more results in flower color mutation as compared to control. In case of EMS treatments (higher doses) achievement was more significant as compare to gamma rays and combination treatments through all mutagenic treatments of Lathyrus sativus Linn.

\section{References}

Borkar A T \& More A D (2010). Induced flower color mutations in Phaseolus vulgaris Linn. through physical and chemical mutagens. Advances in Bioresearch 1(1): 22-28

Campbell C G \& Clayton G (1997). Grass pea (Lathyrus sativus Linn.) Promoting the conservation and use of 
underutilized and neglected crops. Institute of Plant Genetics and Crop Plant Research, Gatersleben/ International Plant Genetic Resources Institute, Rome, Italy

Campbell C G, Mehra R B, Agrawal S K, Chen Y Z, Abdel A M, Moneim H I T, Kawaja C R, Yadav J U \& Araya W A (1994). Current status and future strategy in breeding grasspea (Lathyrus sativus Linn.). Euphytica 73: $167-175$

Girija M, Dhanavel D \& Gnanamurthy S (2013). Gamma rays and EMS induced flower color and seed mutants in cowpea (Vigna unguiculata L. Walp). Advances in Applied Science Research 4(2): 134-139

Kaul A K, Islam M Q \& Hamid A (1986). Screening of Lathyrus germplasm of Bangladesh for BOAA content and some agronomic characters. Third World Medical Research Foundation 11(1): 256-265

Mahamune S E \& Kothekar V S (2011). Gamma ray induced flower color and seed mutants in French bean
(Phaseolus vulgaris L.). Recent Research in Science and Technology 3(5): 33-35

Oluwatosin O B (2001). Inheritance of genes controlling flower color in cowpea (Vigna unguiculata L. Walp). Journal of Genetics and Breeding 1(4): 259-262

Palmer V S, Kaul A K \& Spenser P S (1989). Proceeding of the international network for the improvement of Lathyrus sativus Linn. and the eradication of Lathyrism. Third World Medical Research Foundation 11(1): 219-223

Rathod K L (1989). Status of Lathyrus sativus Linn. in India with special reference to Madhya Pradesh. Third World Medical Research Foundation 11(1): 168-174

Toker C, Uzun B, Canci H \& Ceylan F O (2005). Effects of gamma irradiation on the shoot length of Cicer seeds. Radiation Physics and Chemistry 73: 365-367

Tripathy S K, Lenka D \& Ranjan R (2011). Maximization of mutation of mutation frequency in grasspea (Lathyrus sativus L.). Legume Research 34: 296-299 